\title{
STRES I STRESORY W PRACY WPLYWAJĄCE NA POCZUCIE BEZPIECZEŃSTWA PRACOWNIKA
}

\begin{abstract}
W zindustrializowanym społeczeństwie, gdzie tempo życia ciągle wzrasta, słowo stres słyszy się każdego dnia, gdyż ma ono styczność ze wszystkimi sferami naszego życia. Na przestrzeni wieków zmieniały się czynniki wywołujące stres i tym samym reakcje na nie ulegały swoistemu przekształcaniu. Niewątpliwie stres i stresory wpływają na poczucie bezpieczeństwa pracownika, który zobowiązany jest wykonywać powierzone mu czynności zawodowe w nienaganny sposób. Jest to zjawisko nieuniknione, które oddziałuje na nasze życie prywatne, jak też i zawodowe. Choć najczęściej stres postrzegany jest negatywnie, tym niemniej można znaleźć i pozytywne strony tego zjawiska. Dla jednych stanowi on siłę napędową do aktywności będąc swoistego rodzaju motywatorem do dalszego działania w obranym kierunku, innych hamuje w dalszych poczynaniach i w konsekwencji może doprowadzić do rezygnacji z zajmowanego stanowiska w miejscu pracy, a nawet $\mathrm{i}$ do poważnych zaburzeń w zdrowotnym funkcjonowaniu człowieka. Każdy $\mathrm{z}$ nas reaguje na stres różnorodnie. Stan ten zależny jest od szeregu czynników, które kształtują poczucie danego bezpieczeństwa w miejscy wykonywanej przez pracownika pracy. Jednym z nich niewątpliwie wydają się być prace, które wykonywane są w warunkach niebezpiecznych, np. prace na wysokościach, prace budowlane, ale też te, które wpływają na życie innych ludzi czego najlepszym przykładem jest wykonywanie zawodu lekarza. Artykuł prezentuje poczucie stresu, jak też i podstawowe stresory, które wpływają na poczucie bezpieczeństwa człowieka w miejscu wykonywania swojej pracy zawodowej ukazując jego dwa aspekty pozytywny i negatywny.
\end{abstract}

Słowa kluczowe: stres, stresory, bezpieczeństwo w miejscu pracy

\section{ISTOTA STRESU}

W zależności od dyscypliny nauki zajmującej się pojęciem stresu, istnieją różne jego definicje. Nie jest to pojęcie jednoznaczne, dlatego istnieje wiele koncepcji, które choć ukazują problem w sposób odrębny, tym niemniej nie wykluczają się wzajemnie, a każda z nich ukazuje stres, jako źródło powstania ewentualnego poczucia stanu niebezpieczeństwa. Stresem określa się wewnętrzne reakcje, które są wywołane przez bodźce zewnętrzne tj. strata pracy, utrata bliskiej osoby itp. Jest to nadmierne obciążenie, które odbieramy jako presja, strach, a określamy mianem stres. $\mathrm{W}$ medycynie pojęcie to definiuje się jako stan, w którym ma się do czynienia z zespołem zmian w całym układzie biologicznym

\footnotetext{
${ }^{1}$ Dr Oktawia Jurgilewicz, Katedra Prawa i Administracji, Wydział Zarządzania, Politechnika Rzeszowska im. Ignacego Łukasiewicza, Al. Powstańców Warszawy 6, 35-959 Rzeszów; e-mail: niemieco@prz.edu.pl
} 
człowieka, przez czynnik stresujący. Istotnym zatem aspektem stresu jest subiektywnie odczuwany stan napięcia emocjonalnego ${ }^{2}$.

H. Selye jako pierwszy użył pojęcia stresu w medycynie w $1926 \mathrm{r}^{3}{ }^{3}$ określając ten termin jako niespecyficzną reakcję organizmu na dowolne wymaganie stawiane $\mathrm{z}$ zewnątrz ${ }^{4}$. Autor ten wyróżnił jego dwa aspekty: psychologiczny i fizjologiczny. Aspekt fizjologiczny przejawia się poprzez zaburzenia czynników organizmu i zdrowia, ale również na poziomie behawioralnym, czyli ogólnym dyskomfortem i zaburzeniami zachowania. Natomiast aspekt psychologiczny stresu ma związek z charakterystyką bodźca stresowego, która odzwierciedla jego znaczenie dla życia i rozwoju człowieka. W psychologii zaś posługiwano się trzema definicjami stresu: jako bodźca, reakcji wewnętrznych człowieka, a także jako reakcji między wyżej wymienionymi elementami. Nowoczesne rozumienie zjawiska stresu ukazuje go jako wynik interakcji pomiędzy czynnikami zewnętrznymi i wewnętrznymi. Reakcję zatem organizmu na stresory zewnętrzne określa się jako napięcie 5 .

Według George’a S. Everly Jr. i R. Rosenfelda termin „stres” pochodzi z fizyki, ponieważ odnosi się do różnego typu napięć, nacisków lub sił, które działają na system ${ }^{6}$. Z kolei fińska badaczka Kalimo zdefiniowała stres jako stan napięcia psychicznego wywołany rozbieżnością miedzy wymaganiami otoczenia a możliwościami człowieka. Posiadane możliwości sprawiają, że człowiek postrzega te rozbieżności jako zagrożenie dla swojego zdrowia, życia lub integralności. Czynniki zagrażające tym wartościom nazywają się natomiast stresorami ${ }^{7}$.

W piśmiennictwie naukowym wyróżnia się kilka koncepcji (modeli) stresu, jakkolwiek najczęściej w ramach modelu Coxa zwraca się uwagę zarówno na czynniki wywołujące stres (wymagania, fizyczne i społeczne warunki pracy), jak też na indywidualne charakterystyki jednostki, tj.: aspiracje, zdolności system nastawień, wiedza, doświadczenie, stan zdrowia. To czy wystąpi stres, zależy od reakcji, która zachodzi między tymi czynni$\mathrm{kami}^{8}$.

Z kolei tradycyjną formę stresu obrazuje model Veroński przedstawiający stres, jako relacje między możliwościami jednostki a obciążeniem pracą. Gdy zatem wymagania w stosunku do jednostki są zbyt wygórowane, wówczas powstaje stres, jednakże wtedy pracownik ma też większe możliwości do poradzenia sobie ze stresem. Dodatkowym wskaźnikiem różnicowania zmęczenia i stresu są emocje. W literaturze naukowej wskazuje się, iż lęk, agresja i depresja powodują zwiększenie stanu stresu, bowiem jest on przede wszystkim wynikiem deficytu zasobów i ma miejsce, gdy wymagania stawiane przez sytuacje przerastają możliwości pracownika, a sama sytuacja, w jakiej się on znajduje, oceniana jest jako szkodliwa, zagrażająca bądź wymagająca znacznego wysiłku?

2 J.F. Terelak, Cztowiek $i$ stres, Bydgoszcz 2008, s. 19.

3 G.S. Everly Jr, R. Rosenfeld, Stres. Przyczyny, terapia i autoterapia, Warszawa 1992, s. 13.

${ }^{4}$ W. Oniszczenko, Stres to brzmi groźnie, Warszawa 1998, s. 8.

5 J.F. Terelak, Człowiek..., s. 22.

${ }^{6}$ G.S. Everly Jr, R. Rosenfeld, Stres..., s. 13.

${ }^{7}$ N. Ogińska-Bulik, Stres zawodowy w zawodach ustug spotecznych. Źródta - konsekwencje zapobieganie, Warszawa 2006, s. 17.

8 Tamże, s. 17.

9 Tamże, s. 18. 


\section{RODZAJE STRESU}

W literaturze poświęconej stresowi wyraźnie zaznacza się również podział czynników stresowych wypracowany przez J.A. Singer, M.S. Neale i G.E. Schwartz. Przywołani autorzy pogrupowali te czynniki na siedem poziomów. Pierwsza grupa obejmuje poziom socjokulturalny, do którego zalicza się m.in.: rasizm, seksizm, klęski ekologiczne, zmiany polityczne, czy kryzysy militarne. Kolejna grupa dotyczy poziomu organizacyjnego, tj. polityki zatrudnienia, zamykania zakładów pracy, ograniczenia produkcji, automatyzacji, przesunięcia rynków zbytu, przekwalifikowania oraz priorytetów organizacyjnych. Następny poziom został nazwany organizacyjnym, a zaliczono do niego: zadania (czas, pośpiech, niezależność, kreatywność), nadzór, współpracowników, ergonomię, a także współudział w podejmowaniu decyzji. Pozostałe poziomy to: międzyludzki (rozwody, separacje, kłopoty małżeńskie, konflikty z rodziną i przyjaciółmi, śmierć lub choroba $\mathrm{w}$ rodzinie), psychologiczny (nerwice, choroby psychiczne, zaburzenia emocjonalne, zaburzenia oceny sytuacji i zachowania, kłopoty z samodzielnym działaniem, niska samoocena, słaba komunikatywność), biologiczny (choroba, niepełnosprawność, uzależnienie od środków farmakologicznych), jak również fizyczny (środowiskowy) - są to zanieczyszczenie powietrza, hałas, obecność substancji toksycznych, słabe oświetlenie, radiacja, niewłaściwy dobór narzędzi, zła architektura) ${ }^{10}$.

Niezmiernie istotne wśród badań w dziedzinie psychologii stresu były prace badawcze prowadzone przez T.H. Holmsa i R.H. Rahe, na podstawie których wśród zdarzeń stresowych dnia codziennego, najwyższą rangę stresowości (100 punktów uznaniowych) przypisano śmierci współmałżonka, a najniższą (11 punktów) - drobnym naruszeniom prawa ${ }^{11}$.

Czynniki środowiskowe wywołujące stres, a tym samym wpływające na poczucie bezpieczeństwa można podzielić na sześć kategorii:

- czynniki stresowe tkwiące w samej pracy: presja czasu i bezwzględna terminowość, praca zmianowa, warunki pracy, konieczność nadążania za szybkimi zmianami technologicznymi;

- stosunki społeczne z przełożonymi, podwładnymi i kolegami: brak wsparcia społecznego, wadliwa polityka społeczna, niezdolność do podporządkowania się;

- struktura organizacyjna i klimat emocjonalny: brak współodpowiedzialności, zła komunikacja interpersonalna, poczucie osamotnienia;

- miejsce w organizacji: dwuznaczność roli oraz konfliktowość, nieadekwatna do roli odpowiedzialność za rzeczy i ludzi, zbyt duża zależność od kierownictwa średniego szczebla;

- źródła ekstra organizacyjne: kryzysy życiowe, problemy rodzinne, konflikty w pracy i w domu, trudności natury finansowej, brak wsparcia instytucjonalnego, konflikty związane z mała wiarygodnością i polityka firmy;

- kariera zawodowa: brak perspektyw rozwoju, aktualny status zawodowy, niezgodny z kwalifikacjami i aspiracjami.

Pokonanie stresu wiąże się przede wszystkim z jego poznaniem, a w szczególności $\mathrm{z}$ identyfikacją czynników powodujących jego pojawienie się w naszym codziennym

${ }^{10}$ E. Zielińska, Źródta stresu w środowisku pracy [w:] Stres i jego modelowanie, red. J. Szopa,

M. Harciarek, Częstochowa 2004, s. 211.

11 J.F. Terelak, Psychologia..., s. 32. 
życiu. Tego typu czynniki określa się powszechnie mianem stresorów. Powszechną definicją stresorów jest psychologiczne ich określenie jako wewnętrzne albo zewnętrzne bodźce lub czynniki wywołujące stres, jednakże badacze przedmiotu podają niejednokrotnie znacznie różniące się od siebie definicje określające pojęcie stresorów.

Zgodnie z definicją zaprezentowaną przez N. Ogińską-Bulik stresorami są czynniki, które wywołują u pracownika stan napięcia i silne emocje ${ }^{12}$. Z kolei M. Łoboda charakteryzuje stresory, jako wszelkie formy interakcji jednostki z otoczeniem, powodujące doświadczenie przez nią stresu ${ }^{13}$. Natomiast B. Dudka wyraził pogląd, że stresorem może być każda cecha pracy i warunków, na jakich jest ona wykonywana i która w wyniku oddziaływania na pracownika i subiektywnej interpretacji jej znaczenia, wywołuje u jednostki stan napięcia ${ }^{14}$, czyli stres.

Jeszcze inaczej stresory rozumieli badacze stresu Sutton i Kahn, którzy mianem czynników określali każdy postrzegany subiektywnie lub obiektywnie istniejący czynnik zewnętrzny w postaci wymagania, nacisku, ograniczenia lub deprywacji, który powoduje napięcie objawiające się niezadowoleniem, obniżeniem wydajności czy nawet dolegliwościami somatycznymi ${ }^{15}$.

Przez stresor naukowcy rozumieją także element bodźca lub sytuacji, który narusza względną równowagę pomiędzy podmiotem a środowiskiem, a w konsekwencji uruchamia mechanizmy adaptacyjne zachowania się człowieka ${ }^{16}$, pracownika. I w końcu stresor jest także rozumiany jako zagrożenia, czy to natury fizycznej czy natury psychicznej ${ }^{17}$.

Podsumowując, pod pojęciem stresory oraz czynniki stresowe należy rozumieć wszelkie formy wzajemnego oddziaływania jednostki z otaczającym go środowiskiem. Powodują one powstanie zmian ogólnych, tożsamych lub podobnych dla każdego z rodzajów stresorów, które mają przystosować organizm ludzki i jego system nerwowy do zwiększonych wymagań, czyli innymi słowy powodują doświadczanie przez taką jednostkę stresu.

\section{RODZAJE STRESORÓW}

Czynniki wywołujące stres - stresory - w pracy mogą pochodzić z różnych źródeł. $\mathrm{O}$ ich bycie decydować może sama istota pracy, ale też warunki, w jakich jest wykonywana oraz jej technologia. Relewantnym ich źródłem dla pracownika jest także sama organizacja, a uszczegóławiając - konieczność funkcjonowania w jej ramach, podporządkowania się narzuconym przez nią ograniczeniom, respektowania wielu działań regulacyjnych.

Stres w pracy może również być efektem jednoczesnego działania jednostki w różnych systemach społecznych, konieczności pełnienia w nich odmiennych ról, czy podzielania narzuconych przez nie odmiennych systemów wartości ${ }^{18}$.

\footnotetext{
12 N. Ogińska-Bulik, Stres..., s. 31.

13 M. Łoboda, Stres w pracy zawodowej [w:] Wybrane zagadnienia. Czynniki stresogenne w organizacji, red. A. Biela, Lublin 1990, s. 67.

${ }^{14}$ B. Dudek, M. Waszkowska, W. Hanke, Ochrona zdrowia pracowników przed negatywnymi skutkami stresu zawodowego, Łódź 1999.

${ }_{16}$ N. Ogińska-Bulik, Stres..., s. 31.

16 J.F. Terelak, Psychologia stresu, Bydgoszcz 2001, s. 113.

${ }^{17}$ S. M. Litzke, H. Schuh, Stres, mobbing $i$ wypalenie zawodowe, Gdańsk 2007, s. 12.

18 A. Biela (red.) Stres w pracy zawodowej, Lublin 1990, s. 70.
} 
Stresory, a w szczególności stresory związane w wykonywaniem pracy zawodowej, grupowane są na podstawie różnorodnych kryteriów. Najczęściej ich klasyfikowanie oparte jest na oryginalnych modelach teoretycznych kontekstu organizacyjnego lub środowiska pracy oraz zestawienia stresorów powstałe w oparciu o prowadzone w tym zakresie badania $^{19}$

Pierwszą klasyfikację czynników stresowych w miejscu pracy dokonali Landy i Trumbo. Obejmowała ona następujące stresory zawodowe: niepewność pracy, nadmierne współzawodnictwo, niebezpieczne warunki pracy, wymagania płynące z zadań oraz wydłużone lub nietypowe godziny pracy. Inne pogrupowanie stresorów występujących w miejscu pracy zostało zaprezentowane przez Z. Ratajczaka. Zaliczył do nich: przeciążenie fizyczne pracą, a mianowicie nałożenie na pracownika nadmiernych zadań wymagających wysiłku fizycznego i prowadzących do wyczerpania się jego sił; ogólne przeciążenie umysłowe, którego wskaźnikiem jest obniżenie poziomu funkcjonowania umysłu, tj. procesów uwagi, myślenia, pamięci, oraz nadmierne uproszczenie czynności; jakościowe przeciążenie pracą polegające na wykonywaniu zadań złożonych, niejasnych lub konfliktowych, presję czasu, monotonię, niesprawiedliwe traktowanie przez przełożonych, które najczęściej przejawia się w faworyzowaniu innych, mniej zasłużonych, ale także w niedostrzeganiu zasług i możliwości pracownika oraz jego wkładu w realizację zadań zbiorowych, brak wyraźnych osiągnięć w pracy zawodowej, czy brak możliwości współdecydowania, brak uznania społecznego w środowisku pracy.

Autor ten zwrócił uwagę na okoliczność, że zwykle stres pojawia się tam, gdzie zadanie stawiane pracownikowi było przez niego postrzegane jako trudne, a trudność ta jest niejasna i nie wiadomo, na czym ona polega. Dalej wskazał, że ma to miejsce, gdy człowiek stara się sprostać takiemu trudnemu zadaniu - traktuje je jako pewnego rodzaju wyzwanie, a niepodjęcie tego wyzwania zaburza mu obraz własnej osoby, ale także, gdy następuje wyczerpanie się zapasów energii pracownika (fizycznej i psychicznej) $)^{20}$.

Najbardziej znany w literaturze naukowej podział stresorów związanych z wykonywaną pracą został dokonany przez trzy grupy naukowców: Levi ego i Frankenhauesera, Ivancevicha i Mattesona oraz Coopera i Marshalla.

Pierwsi z nich wskazywali, że głównym źródłem stresu są w takim samym stopniu czynniki fizyczne i czynniki społeczne, przy czym uważali, że na spostrzeganie warunków i wymagań pracy jako stresujących mają wpływ następujące cechy osobowościowe pracownika, tj. niezrównoważenie emocjonalne, konformizm, brak inicjatyw, sztywność postawy, trudności adaptacyjne i niski poziom motywacji osiągnięć. Wykreowany przez nich podział stresorów obejmuje:

- czynniki stresowe tkwiące $\mathrm{w}$ samej pracy, tj.: jakościowe i ilościowe przeciążenie pracą, presja czasu i bezwzględna terminowość, warunki pracy, praca zmianowa, konieczność nadążania za szybkimi zmianami technologicznymi;

- stosunki społeczne z przełożonymi, podwładnymi, kolegami, tj.: niezdolność podporządkowania się, brak wsparcia społecznego, wadliwa polityka społeczna;

- struktura organizacyjna i klimat emocjonalny, tj.: brak współodpowiedzialności, poczucie osamotnienia, zła komunikacja interpersonalna;

${ }^{19}$ N. Ogińska-Bulik, Stres..., s. 31.

${ }^{20}$ Z. Ratajczak, Wsparcie spoteczne w środowisku pracy a stres i jego skutki zdrowotne [w:] Psychologiczna problematyka wsparcia społecznego i pomocy, red. Z. Ratajczak, Katowice 1994, s. $57-63$. 
- miejsce w organizacji, tj.: dwuznaczność roli i konfliktogenność, nieadekwatna do roli odpowiedzialność za rzeczy i ludzi, zbyt duża zależność od kierownictwa średniego szczebla;

- źródła ekstra organizacyjna, tj.: problemy rodzinne, kryzysy życiowe, trudności finansowe, konflikty związane $\mathrm{z}$ małą wiarygodnością i polityką firmy, konflikty w pracy i w domu, brak wsparcia instytucjonalnego;

- kariera zawodowa, tj.: aktualny status zawodowy niezgodny $\mathrm{z}$ kwalifikacjami i aspiracjami, brak perspektyw rozwoju ${ }^{21}$.

Zaprezentowana koncepcja została rozwinięta przez pozostałe dwie grupy naukowców. W następstwie ich badań wyróżniono stresory wewnątrzorganizacyjne i ekstraorganizacyjne. Czynniki stresowe wewnątrzorganizacyjne to:

- środowisko fizyczne: temperatura, hałas, oświetlenie, wibracje;

- organizacyjne czynniki stresowe: zły klimat organizacyjny, zły styl zarządzania, stosowany system kontroli, przestarzała technologia;

- grupowe czynniki stresu: brak spójności grupy, konflikty wewnątrz grupy;

- niezadowolenie grupy z lidera;

- indywidualne obciążenie pracą: konflikt roli, brak perspektyw zawodowych, odpowiedzialność za innych, przeciążenie.

Natomiast do stresowych czynników ekstraorganizacyjnych zostały zaliczone stosunki rodzinne, nietolerancja wyznaniowa, problemy rasowe, zbyt duża konkurencja na rynku pracy oraz problemy ekonomiczne kraju. Dodatkowo wskazano sześć czynników sprawczych stresu w pracy:

- czynniki związane z wykonywaną pracę, tj. presję czasową, złe warunki pracy, niedociążenie względnie przeciążenie, pracę zmianową, a także właściwości materialnego środowiska pracy;

- czynniki związane z pełnionymi rolami, tj. niejednoznaczność roli, odpowiedzialność za podwładnych, brak udziału w podejmowaniu decyzji, konflikt ról;

- czynniki związane ze złymi stosunkami w pracy, tj. złe stosunki ze współpracownikami, podwładnymi, szefem oraz problemy z delegowaniem odpowiedzialności;

- czynniki związane z rozwojem zawodowym, tj. brak pewności zatrudnienia, niezaspokojone ambicje, a także zbyt szybki bądź zbyt wolny awans;

- czynniki związane ze struktury organizacyjnej i atmosfery $\mathrm{w}$ pracy, $\mathrm{tj}$. polityka etatowa, ograniczenie aktywności;

- czynniki związane z pozaorganizacyjnymi źródłami stresu, tj. problemy rodzinne, trudności finansowe, kryzysy życiowe, konflikty między oczekiwaniami pracodawcy a potrzebami rodziny ${ }^{22}$.

Całkowicie odmienny podział czynników od wyżej zaprezentowanych został opracowany w oparciu o rodzaj stresu, jakie wywołują. Stresory podzielono na te, które wywołują stres krótkotrwały, aczkolwiek charakteryzujący się gwałtownością i intensywnością oraz stres chroniczny. Ten pierwszy wywołują hałas, tłok, izolacja, głód, zagrożenie, infekcje, a także wyobrażenie zagrożenia bądź wspomnienie niebezpiecznego zdarzenia, natomiast stres chroniczny jest z kolei skutkiem samotności, stałej presji przełożonych, długotrwałych problemów w stosunkach koleżeńskich, ustawicznych problemów finan-

${ }^{21}$ N. Ogińska-Bulik, Stres..., s. 32-33.

22 Tamże, s. 34. 
sowych. Jednakże powszechnie, w związku z brakiem odpowiedniego kryterium podziału czynników stresogennych, przyjmuje się ich zróżnicowanie ze względu na naturę tych stresorów. Wyróżnia się stresory fizyczne, chronobiologiczne i psychologiczne (społeczne, czy psychospołeczne) $)^{23}$.

\section{STRESORY FIZYCZNE}

Fizyczne czynniki stresu cechują się dwoma znamionami, nie sprawiają większych trudności z ujęciem w kategoriach ilościowych, a także można za ich pomocą dokonać opisu zewnętrznego środowiska jednostki. Te cechy powodują, że względnie łatwo można wyznaczyć próg stresu - moment, w którym bodziec irrelewantny dla organizmu wyzwala działanie mechanizmów adaptacyjnych, aby sprostać zwiększonym, do tej pory nieznanym wymaganiom, a także próg tolerancji stresu - moment, w którym organizm ponosi straty, w sytuacji gdy mechanizmy adaptacyjne są nieadekwatne do zmienionej sytuacji lub gdy organizm odmawia działania ${ }^{24}$. Do stresorów fizycznych zalicza się przede wszystkim: czynniki klimatyczne, hałas, wibracje, niedotlenienie, oświetlenie, promieniowanie, hipoksję, przyśpieszenia, a także nieważkość.

\subsection{Czynniki klimatyczne}

Warunki klimatyczne panujące w miejscu wykonywania pracy przez jednostkę są niezmiernie istotne. Jakiekolwiek ich odchylenie od normy rodzi konsekwencje w postaci odczucia wzrostu uciążliwości pracy, pogorszeniu jej efektywności, zwiększeniu się ryzyka wypadków przy pracy bądź powstania chorób zawodowych. Czynniki klimatyczne obejmują w szczególności temperaturę powietrza, wilgotność, ciśnienie atmosferyczne, promieniowanie cieplne czy nawet ruchy powietrza. Stresogenny charakter powyższych czynników ujawnia się w takich sytuacjach, jak zmiana warunków geograficznych, pór roku, zmiana strefy klimatycznej, ale także w ich znaczącym natężeniu oddziaływania względnie odczuwalnym zminimalizowaniu. Zauważyć przy tym należy, że każda jednostka posiada wrodzone oraz nabyte zdolności oceny stanu warunków klimatycznych. $\mathrm{Z}$ uwagi na to jako miarę komfortu przyjmowane są subiektywne odczucia tych warunków przez człowieka, które uzależnione są przede wszystkim od stanu zdrowia, wieku, przyzwyczajeń oraz odporności jednostki.

\subsection{Hałas}

Ucho jest jednym $\mathrm{z}$ najważniejszych narządów odbierającym bodźce zewnętrzne. Dostarcza ono istotnych informacji o zmianach zachodzących w środowisku zewnętrznym. Hałas jest pojmowany jako bodźce dźwiękowe wywołujące w narządzie słuchu dźwięk, które jednakże uznawane są za niepożądane. Zazwyczaj hałas może być opisany przy pomocy dwóch parametrów fizycznych.

Pierwszym jest częstotliwość, która określa liczbę całkowitych fal akustycznych, docierających do ucha w jednostce czasu i wyznaczana jest w okresach na sekundę lub

${ }^{23}$ E. Zielińska, Źródta..., s. 214.

${ }^{24}$ J.F. Terelak, Psychologia..., s. 114. 
w hercach, Drugim zaś jest natężenie - strumień energii przypadającej na jednostkę powierzchni, określany w decybelach ${ }^{25}$.

Odróżnienie hałasów szkodliwych, czyli stresogennych od hałasów nieszkodliwych, obojętnych dla organizmu ludzkiego w praktyce niesie ze sobą wiele trudności. Jest to wynikiem okoliczności, że stresogenność hałasu jest uzależniona od natężenia dźwięku, charakterystyki jego częstotliwości oraz czasu jego trwania ${ }^{26}$. Stresowy charakter hałasu wynika z kilku powodów. Przede wszystkim może on powodować uszkodzenie narządu słuchu, dalej wpływa na zmęczenie układu nerwowego, a także powoduje ogólny dyskomfort, bowiem utrudnia komunikację werbalną.

Omawiany stresor obniża wydajność pracy, co ma związek z utrudnioną komunikacją werbalną i rozproszeniem uwagi. Pogorszona słyszalność utrudnia odbieranie dźwiękowych sygnałów ostrzegawczych, czego skutkiem zwykle jest wzrost wypadków przy pracy. Hałas powoduje dyskomfort psychiczny oraz powstanie zmian wegetatywnych, do których zaliczane są zmiany w czynnościach układu krążenia (m.in. zwężenie obwodowych, drobnych naczyń krwionośnych oraz zmniejszenie objętości wyrzutowej i minutowej serca), rozwój nadciśnienia tętniczego, choroby wrzodowej żołądka i dwunastnicy ${ }^{27}$. Specyficzną właściwością hałasu jest to, że „w przeciwieństwie do wielu innych wpływów otoczenia nie rozwija się adaptacja fizjologiczna do hałasu" 28 , tak więc jedyną formą obrony przed hałasem jest jego próba ograniczenia.

\subsection{Wibracje}

Czynnik ten ma podobny charakter do hałasu. Wibracjami są drgania mechaniczne przenoszone ze środowiska zewnętrznego na zasadzie rezonansu na organizm ludzki. Prowadzone badania naukowe jednoznacznie potwierdziły, że drgania mechaniczne o częstotliwości od 1 do $100 \mathrm{~Hz}$ są szkodliwe dla człowieka, bowiem wywołują tzw. zjawisko rezonansu, które zachodzi przy bardzo niskich częstotliwościach oraz absorbują w tkankach energię mechaniczną drgań. Wpływ wibracji lokalny (przeważnie na ręce), jak i ogólny, wywołuje w organizmie jednostki niekorzystne skutki, wśród których wymienia się: zmiany w układzie kostno-stawowym, zmiany niedokrwienne związane ze skurczami naczyń krwionośnych, lęki, objawy choroby Reynauda (charakteryzującej się napadowymi skurczami tętnic w obrębie rąk lub stóp), obniżenie percepcji wzrokowej i ruchowej (tzw. tremor rąk i nóg). Nadto wibracje wywołują subiektywnie odczuwane objawy ogólnego dyskomfortu, objawiającego się jako znużenie i zmęczenie ${ }^{29}$. Efekt działań drgań mechanicznych jest także uzależniony od przemieszczania się względem siebie narządów lub tkanek.

\subsection{Oświetlenie}

Wadliwe oświetlenie miejsc pracy traktuje się jako czynnik stresowy, ponieważ w takich warunkach jednostki zmuszone są do wypracowania i nauczenia się indywidualnych strategii pokonywania trudności w odbiorze informacji wzrokowej. Czynnik ten jest

\footnotetext{
25 Tamże, s. 121.

${ }^{26}$ S. Wieczorek, Podstawy psychologii pracy i ergonomii, Tarnobrzeg 2005, s. 124.

27 J.F. Terelak, Psychologia..., s. 123.

28 S. Kozłowski, Granice przystosowania, Warszawa 1986, s. 414.

${ }^{29}$ J.F. Terelak, Psychologia..., s. 124.
} 
przyczyną powstawania błędów w pracy i wydłużenia się czasu realizacji poszczególnych czynności. Zagwarantowanie właściwego oświetlenia stanowisk pracy jest jednym z ważniejszych warunków wydajnej i efektywnej pracy, higieny wzroku, a także podniesienia estetyki wnętrza pomieszczeń. Aby działalność wzroku mogła dokonać się w warunkach optymalnych, warunki oświetleniowe powinny spełniać konkretne wymogi psychofizjologiczne narządu widzenia, które uzależnione są od rodzaju wykonywanej pracy. Zadaniem właściwego oświetlenia jest zapewnienie wymaganej ostrości widzenia, szybkości postrzegania i akomodacji. Praca powinna być wykonywana bez nadmiernego zmęczenia układu nerwowego, bezbłędnie, a przede wszystkim winna wiązać się z dobrym samopoczuciem pracownika ${ }^{30}$. Stanem wywołującym dyskomfort widzenia i drastycznie obniżającym zdolność rozpoznawania przedmiotów jest tzw. olśnienie. Olśnieniem nazywa się stan procesu widzenia, przy którym występuje odczucie niewygody lub zmniejszenie zdolności rozpoznawania przedmiotów bądź jedno i drugie, w wyniku niewłaściwego rozkładu luminancji lub niewłaściwego zakresu luminancji albo nadmiernych kontrastów w przestrzeni lub w czasie ${ }^{31}$. Podobnie się ma rzecz ze stresogennym charakterem migotania światła, czy to wadliwie funkcjonujących świetlówek, czy migocącym ekranem telewizora lub komputera.

\section{STRESORY CHRONOBIOLOGICZNE}

Czynniki chronobiologiczne zostały wyodrębnione w związku z badaniami mającymi na celu analizę i opis cyklicznych powtarzających się zjawisk występujących w życiu jednostki, czyli rytmicznych zmian jej czynności życiowych. Głównym i najistotniejszym takim stresorem jest tzw. rytm okołodobowy. Ma on charakter sinusoidalny, co oznacza, że wykazuje on wartości maksymalne w godzinach popołudniowych, zaś wartości minimalne $\mathrm{w}$ porze nocnej, $\mathrm{z}$ dużymi wahaniami w zależności od właściwości osobniczych jednostki. Ludzki zegar biologiczny daje możliwość dostosowania procesów życiowych organizmu do periodycznych zmieniających się pór roku, przez co rozumie się, że wszelkie działania jednostki (praca, aktywny wypoczynek) powinny przypadać na godziny dzienne, zaś w godzinach nocnych organizm winien odpoczywać w trakcie snu. Jednakże W związku z istniejącymi niekorzystnymi warunkami środowiskowymi czy też obyczajami współczesnego człowieka zegar biologiczny może ulec rozregulowaniu. Nieuregulowany tryb życia, jako efekt pracy zmianowej, skutkuje nieprawidłowym biegiem zegara biologicznego, co może w konsekwencji powodować powstanie dolegliwości zdrowotnych. Fizjologiczny problem pracy na zmiany jest efektem podejmowania aktywności zawodowej w porach niewspółgrających w właściwym rytmem dobowym czynności fizjologicznych. Dotyczy to w znaczącej liczbie przypadków wpływu pracy w porze nocnej na okołodobowy rytm snu i czuwania. Dodatkowo wykonywanie pracy w ciasnych pomieszczeniach, w których jednostka jest narażona na odczucie chłodu, w których znajduje się słabe oświetlenie, hałas i zawodny sprzęt jest niezaprzeczalnie poważnym obciążeniem i może być czynnikiem powodującym pojawienie się stresu. Źle zaprojektowane pomieszczenia, w których brak jest dostępu światła słonecznego, zaś pracownik jest nie-

\footnotetext{
${ }^{30}$ M. Hartley, Stres w pracy, Kielce 2005, s. 85.

${ }^{31} \mathrm{http} / / /$ www.lenalighting.pl/bank-wiedzy/olsnienie/ (dostęp: 13.12.2017 r.).
} 
jako skazany na jaskrawe lampy, w których panuje chaos rozmaitych sprzętów, zaś dobór współpracowników jest przypadkowy, na nikogo nie oddziałuje korzystnie ${ }^{32}$.

\section{STRESORY PSYCHOSPOLECZNE}

Czynniki psychospołeczne powstają w konkretnych społecznych oraz organizacyjnych warunków pracy, a ich negatywny dla zdrowia wpływ wyznaczany jest psychologiczną oceną znaczenia, jakie mają dla pracownika, to znaczy czy stanowią zagrożenie, ograniczenie, pozbawienie doniosłych wartości bądź wyzwanie dla jej zdolności, dążeń ${ }^{33}$. Ocena istoty elementu pracy powoduje wystąienie danej emocji, która jest przyczynkiem prowadzącym do powstania następnych zmian w organizmie jednostki, mogących być przyczyną utraty zdrowia.

\subsection{Przeciążenie i niedociążenie pracą}

Rodzaj tej sytuacji stresowej wynika zarówno z przeciążenia ilościowego - zbyt dużo pracy, jak i przeciążenia jakościowego - praca zbyt trudna. Przeciążenie jest sytuacją niezwykle niekorzystną, wynika ono z wykonywania czynności na granicy swoich możliwości fizycznych bądź psychicznych ${ }^{34}$. Zdaniem badaczy tego zjawiska przy dużej ilości pracy znamienna jest kontrola jednostki nad jej tempem wykonywania pracy, niż ilość tej pracy. Im pracownik ma mniejszą kontrolę na tempem pracy, tym większy odczuwa stres $^{35}$. Stresor ten występujący w długotrwałych sytuacjach pociąga za sobą szukanie zapomnienia $\mathrm{w}$ alkoholu, absencji $\mathrm{w}$ pracy, niską motywację $\mathrm{w}$ pracy, niskie poczucie własnej wartości, stałe napięcie psychiczne, czy w krańcowych sytuacjach poczucie zagrożenia. Natomiast jeżeli przeciążenie jest stanem krótkotrwałym, to prowadzi co najwyżej do zmęczenia lub wyczerpania. Przez niedociążenia pracą określa się zjawisko wykonywania przez jednostkę pracy zbyt prostej, niewymagającej i niezapełniającej całego czasu pracy bądź niedostatecznie absorbującej posiadane przez pracownika kompetencje.

\subsection{Rola organizacyjna}

Pojęciem roli organizacyjnej określa się standaryzowany wzorzec zachowań wymaganych od osoby pozostającej w określonej zależności funkcjonalnej od innych uczestników procesu pracy ${ }^{36}$. Do czynników stresowych dotyczących roli organizacyjnej zalicza się ${ }^{37}$ :

- konflikt roli - dotyczy on sytuacji, w których jednostka odbiera jednocześnie kilka sprzecznych ze sobą przekazów roli, które niekiedy wykluczają się, przyjmuje się, że osoby, które postrzegają swoją rolę jako niedookreśloną, są niezadowolone $\mathrm{z}$ wykonywanej pracy, odczuwają duże napięcie nerwowe w trakcie jej wykonywania i cechują się mniejszą wiarą w we własne siły. Jednostki dotknięte konflik-

\footnotetext{
${ }^{32}$ S. Cymborowski, Zegary biologiczne, Warszawa 1989, s. 178.

33 W. Szewczuk, Psychologia, Warszawa 1990, s. 67.

${ }^{34}$ J.F. Terelak, Psychologia..., s. 190.

35 D.P. Schutz, S.E. Schutz, Psychologia a wyzwania dzisiejszej pracy, Warszawa 2000, s. 438.

36 D. Katz, R.L. Kahn, Spoteczna psychologia organizacji, Warszawa 1979, s. 64.

${ }^{37}$ A. Bańka, Psychologia pracy, Poznań 1996, s. 104.
} 
tem roli doświadczają mniejszej satysfakcji z pracy, a także darzą mniejszym zaufaniem organizację oraz reprezentujących ją zwierzchników ${ }^{38}$;

- niejednoznaczność roli - stresor ten odnosi się do przypadków, w których pracownik dysponuje nieadekwatnymi informacjami o swojej roli, tzn. nie potrafi rozpoznać celu wykonywanej pracy, oczekiwań osób z nią współpracujących, zakresu odpowiedzialności czy też wyników pracy. Według psychologów pracy na niejednoznaczność roli składają się trzy czynniki: niejednoznaczność kryteriów wykonywanych zadań, niejednoznaczność schematów, niejednoznaczność metod ${ }^{39}$.

\subsection{Odpowiedzialność}

W trakcie wykonywania pracy pracownik ponosi mniejszą lub większą odpowiedzialność, czy to materialną, czy to za efekt pracy wykonywanej przez niego lub przez zespół w którym się znajduje. Generalnie przyjmuje się, że odpowiedzialność materialna nie jest czynnikiem powodującym powstanie stresu. Jednakże stres taki pojawia się, gdy jednostka odpowiada za współpracowników bądź podwładnych, a jej zasadniczym zadaniem jest nadzorowanie i kontrolowanie pracy innych oraz składanie sprawozdań w ściśle określonym terminie ${ }^{40}$.

\subsection{Relacje interpersonalne}

Istotnym źródłem stresu w pracy jest charakter stosunków pracownika z przełożonymi, podwładnymi czy współpracownikami. Wielu przedstawicieli nauk behawioralnych prezentuje pogląd, iż dobre stosunki w grupie pracowniczej są najważniejszym warunkiem zdrowia człowieka i dobrego funkcjonowania kolektywu ${ }^{41}$. Badania wskazują, że mniej niż dwadzieścia pięć procent współpracowników jest uważanych przez jednostkę za przyjaciół, zaś pięćdziesiąt procent osób czynnych zawodowo nie znajduje przyjaźni w miejscu pracy ${ }^{42}$. Jednocześnie zaznacza się, że pomiędzy brakiem zaufania do współpracowników a dużą niejednoznacznością roli istnieje dodatnia korelacja, która powoduje trudności w skutecznym porozumiewaniu się ludzi, a także wprowadza stan napięcia psychicznego przejawiającego się niezadowoleniem z pracy oraz poczuciem zagrożenia własnego zdrowia ze strony tejże pracy ${ }^{43}$.

Omawiane stresory obejmują złe relacje z współpracownikami, złe stosunki z przełożonymi bądź podwładnymi. Jednostka wraz ze współpracownikami jest składową grupy roboczej, której oddziaływanie może być genezą stresu bądź satysfakcji. Środowisko pracy często trapione jest wielorakiego rodzajami konfliktami, których podłożem zazwyczaj są tzw. złe relacje. Charakteryzują się one brakiem zaufania, wzajemną niechęcią, skłóceniem. Wśród negatywnych konsekwencji takiego stanu wymienia się spadek samooceny, pogorszenie samopoczucia jednostki (psychicznego i fizycznego), znaczącą utratę pewności $\operatorname{siebie}^{44}$, a także trudnością w koncentracji, irytacją i frustracją. Dodatkowo

\footnotetext{
38 D. Koradecka (red.), Bezpieczeństwo pracy i ergonomia, Warszawa 2000, s. 167.

${ }^{39}$ D.P. Schutz, S.E. Schutz, Psychologia ..., s. 440.

${ }^{40}$ N. Ogińska-Bulik, Stres..., s. 35.

${ }^{41}$ Tamże, s. 35.

${ }^{42}$ R.J. Edelmann, Konflikty w pracy, Gdańsk 2003, s. 9.

${ }^{43}$ N. Ogińska-Bulik, Stres..., s. 35.

44 R.J. Edelmann, Konflikty..., s. 56.
} 
jednostkę nieakceptowaną w grupie trapią różnego rodzaju symptomy fizyczne: przewlekłe bóle głowy, problemy ze snem i z układem trawiennym, wysokie ciśnienie czy wrzody żołądka ${ }^{45}$.

Do silnych czynników stresogennych zalicza się również tzw. mobbing. Oznacza on „działania lub zachowania polegające na uporczywym i długotrwałym nękaniu lub zastraszaniu pracownika, wywołujące u niego zaniżoną ocenę przydatności zawodowej, powodujące lub mające na celu poniżenie lub ośmieszenie pracownika, izolowanie go lub wyeliminowanie z zespołu współpracowników"46. Zjawisko to przeważnie pojawia się tam, gdzie jednostka traktowana jest w sposób przedmiotowy, instrumentalny, gdzie organizacja oparta jest na silnej hierarchii, a także gdzie pracownicy mają dużo pracy, zaś ich wartość oceniana jest w oparciu o wydajność pracy ${ }^{47}$.

Poruszona problematyka dotyczy stresu, jak również stresorów w miejscu pracy, które implikują bezpieczeństwo pracownika niewątpliwie mają charakter zróżnicowany, jakkolwiek ich powszechna znajomość pozwala reagować na istniejące w tym obszarze zagrożenia, które w efekcie mogą wpłynąć na komfort pracy, jak również wyeliminować ryzyka związane $\mathrm{z}$ ich urealnieniem.

\section{Literatura}

[1] Bańka A., Psychologia pracy, Wyd. Gemini, Poznań 1996.

[2] Biela A. (red.) Stres w pracy zawodowej, Wyd. KUL, Lublin 1990.

[3] Cymborowski S., Zegary biologiczne, Wyd. PWN, Warszawa 1989.

[4] Dudek B., Waszkowska M., Hanke W., Ochrona zdrowia pracowników przed negatywnymi skutkami stresu zawodowego, Wyd. Instytut Medycyny Pracy, Łódź 1999.

[5] Edelmann R.J., Konflikty w pracy, Wyd. GWP, Gdańsk 2003.

[6] Everly Jr G.S., Rosenfeld R., Stres. Przyczyny, terapia i autoterapia, Wyd. Naukowe PWN, Warszawa 1992.

[7] Hartley M., Stres w pracy, Wyd. Jedność, Kielce 2005.

[8] Katz D., Kahn R.L., Społeczna psychologia organizacji, Wyd. PWN, Warszawa 1979.

[9] Koradecka D. (red.), Bezpieczeństwo pracy i ergonomia, Wyd. CIOP, Warszawa 2000.

[10] Kozłowski S., Granice przystosowania, Wyd. Wiedza Powszechna, Warszawa 1986.

[11] Litzke S.M., Schuh H., Stres, mobbing i wypalenie zawodowe, Wyd. GWP, Gdańsk 2007.

[12] Łoboda M., Stres w pracy zawodowej [w:] Wybrane zagadnienia. Czynniki stresogenne w organizacji, red. A. Biela, Wyd. KUL, Lublin 1990.

[13] Oniszczenko W., Stres to brzmi groźnie, Warszawa 1998.

[14] Ogińska-Bulik N., Stres zawodowy w zawodach ustug społecznych. Źródła - konsekwencje - zapobieganie, Wyd. Difin, Warszawa 2006.

[15] Ratajczak Z., Wsparcie społeczne w środowisku pracy a stres i jego skutki zdrowotne [w:] Psychologiczna problematyka wsparcia spotecznego i pomocy, red. Z. Ratajczak, Wyd. Uniwersytetu Śląskiego, Katowice 1994.

[16] Schutz D.P., Schutz S.E., Psychologia a wyzwania dzisiejszej pracy, Wyd. PWN, Warszawa 2000.

\footnotetext{
45 Tamże, s. 12.

46 A. Świątkowski, Kodeks pracy. Komentarz, Warszawa 2012, s. 198.

${ }^{47}$ N. Ogińska-Bulik, Stres..., s. 39.
} 
[17] Szewczuk W., Psychologia, Wyd. WiSP, Warszawa 1990.

[18] Świątkowski A., Kodeks pracy. Komentarz. Wyd. C.H. Beck, Warszawa 2012.

[19] Terelak J.F., Psychologia stresu, Wyd. Oficyna Wydawnicza BRANTA, Bydgoszcz 2001.

[20] Terelak J.F., Człowiek i stres, Wyd. Branta, Bydgoszcz 2008.

[21] Wieczorek S., Podstawy psychologii pracy i ergonomii, Wyd. Tarbonus, Tarnobrzeg 2005.

[22] Zielińska E., Źródła stresu w środowisku pracy [w:] Stres i jego modelowanie, red. J. Szopa, M. Harciarek, Wyd. Wydziału Zarządzania Politechniki Częstochowskiej, Częstochowa 2004.

\section{STRESS AND STRESSORS AT WORK THAT AFFECT THE EMPLOYEE'S SENSE OF SECURITY}

In an industrialized society where the pace of life is constantly increasing, the word stress is heard every day because it is in contact with all spheres of our lives. Over the centuries, factors causing stress have changed, and thus the reactions to them have undergone a specific transformation. Undoubtedly, stress and stressors affect the sense of security of the employee, who is obliged to perform the professional activities entrusted to him in an impeccable manner. This is an unavoidable phenomenon that affects our private as well as professional life. Although the most often perceived negatively but delving into the presented issue, one can find and positive sides of this phenomenon. For some it is the driving force for action being a kind of motivator for a further action in the chosen direction, while others inhibit further actions and consequently may lead to resignation from occupational positions and even serious disturbances in the health of human functioning. Each of us reacts to it differently. This condition depends on a number of factors that shape the sense of a given safety in a job performed by a worker. One of them undoubtedly seem to be works that are carried out in dangerous conditions, e.g. works at heights, construction works but also works that affect the lives of other people, the best example being the profession of a medical doctor. The article presents a sense of stress as well as basic stressors that affect the sense of security of the human at the place of performing their professional work, showing its two aspects - positive and negative.

Keywords: stress, stressors, safety at work

DOI: $10.7862 /$ rz.2017.mmr.41

Tekst złożono w redakcji: grudzień 2017 r.

Przyjęto do druku: styczeń 2018 r. 
